\title{
Modeling of eucalyptus tree stem taper in mixed production systems
}

\author{
Modelagem do afilamento do fuste de árvores de eucalipto em sistemas \\ consorciados de produção
}

\author{
Clebson Lima Cerqueira' (1), Rômulo Môra ${ }^{2}$ (D), Helio Tonini ${ }^{3}$ (D), Julio Eduardo Arce $^{1}$ (1), \\ Samuel de Pádua Chaves Carvalho² (1), Diogo Guido Streck Vendruscolo ${ }^{4}$ (1) \\ ${ }^{1}$ Universidade Federal do Paraná - UFPR, Curitiba, PR, Brasil \\ ${ }^{2}$ Universidade Federal do Mato Grosso - UFMT, Cuiabá, MT, Brasil \\ ${ }^{3}$ Embrapa Pecuária Sul, Bagé, RS, Brasil \\ ${ }^{4}$ Proterra-Projetos, Agrimensura \& Ambiental, Alto Boa Vista, MT, Brasil
}

How to cite: Cerqueira, C. L., Môra, R., Tonini, H., Arce, J. E., Carvalho, S. P. C., \& Vendruscolo, D. G. S. (2021). Modeling of eucalyptus tree stem taper in mixed production systems. Scientia Forestalis, 49(130), e3186. https://doi.org/10.18671/scifor.v49n130.22

\begin{abstract}
This work's objective was to evaluate the taper estimates obtained from the mixed-effect modeling function and verify the effect of planting spacing and arrangement forthe eucalyptus tree stem form in a Crop-Livestock-Forest integration system (iCLF). Data wasgathered from an experimental iCLF area, implemented by the Brazilian Agricultural Research Company (EmpresaBrasileira de PesquisaAgropecuária-EMBRAPA Agrossilvipastoril), located in the municipality of Sinop, State of Mato Grosso, Brazil. The database used in the research developmentconsisted of the destructive cubing of 186 51-month-old trees. The modeling performance was evaluated through fit statistics and graph analysis. The model identity test evaluated the influence of the different planting arrangements on tree stem form. The mixed-effect modeling featured greater accuracy for estimating the eucalyptus taper in the iCLF system and the planting spacing and arrangement for the tree stem form.
\end{abstract}

Keywords: Stem form; Mixed-effect modeling; Crop-Livestock-Forest integration.

\section{Resumo}

Neste trabalho objetivou-se avaliar as estimativasobtidas por funções de afilamento commodelagem deefeitosmistos e verificar o efeito do espaçamento e arranjo de plantiona forma do fuste deárvores de eucaliptoemsistema de integraçãoLavoura-Pecuária-Floresta (iLPF). Os dados foramcoletadosemumaárea experimental de iLPF, implantada pela EmpresaBrasileira de PesquisaAgropecuária-EMBRAPA Agrossilvipastoril, localizada no município de Sinop, estado de Mato Grosso. A base de dados utilizada no desenvolvimento da pesquisafoicomposta pela cubagemdestrutiva de186 árvoresaos 51 meses de idade. O desempenho da modelagemfoiavaliado por meio de estatísticas de ajustee análisegráfica.Ainfluência dos diferentesarranjos de plantiona forma do fuste das árvoresfoiavaliadapelo teste de identidade de modelos. A modelagem de efeitosmistosapresentoumaioracurácia para estimativa do afilamento de eucaliptoemsistema de iLPF e o espaçamento e arranjo de plantioinfluênciana forma do fuste das árvores.

Palavras-chave: Forma do fuste; Modelagem de efeitos mistos; Integração Lavoura-Pecuária-Floresta.

Financial support: Embrapa Agrossilvipastoril, Conselho Nacional de Desenvolvimento Científico e Tecnológico (CNPQ).

Conflict of interest: Nothing to declare.

Corresponding author: clebson.mensuracao@gmail.com

Received: November 8, 2018.

Accepted: October 19, 2020

Editor: Paulo Henrique Müller Silva. 


\section{INTRODUCTION}

Brazil is regarded as a world reference in the production of grains, animal protein, and products derived from planted forests. The country's significant production is related to the growing demand for several products from food crops, livestock, and forest origin. Therefore, different crop alternatives intended forhigher productivity are being suggested, such as the Crop-Livestock-Forest integration (iCLF) systems.

At iCLF systems, crops, trees, pastures, and animals are integrated towards potentializing environmental and economic interactions (Torres et al., 2016). Such production systems are increasing via stimulation programs, such as the Low Carbon Agriculture Program (Programa Agricultura de Baixo Carbono - ABC), which was implemented by Act no. 12,187, dated December 29, 2009, creating the Nationwide Climate Change Policy (Política Nacional sobre Mudanças do Clima - PNMC).

With the increase and stimulation in adopting integrated production systems, producers' and forest managers' need and interest in handling the forest component, intend to quantify production, since this information subsidizes forest planning (Figueiredo Filho et al., 2015). To this purpose, statistics- and computer tooling-based modeling techniques are used to obtain accurate production estimates. Among the several techniques used in Brazil and worldwide, there are taper functions, which can be used for stem for studies, volumetric estimate, and woodvarieties (Campos \& Leite, 2013).

The tree stem form modeling in established monoculture stands is a topic widespread in the Brazilian forest sector, with several studies developed and proposed for representing the stem profile of species with more significant economic species, such as those from Eucalyptus (Souza et al., 2016), Pinus Taeda (Nogueira et al., 2008), Araucaria angustifolia (Figueiredo Filho et al., 2015), and Tectona grandis (Vendruscolo et al., 2016) genus. However, Eucalyptus clone stem form approaches in iCLF are still scarce, standing out the work by (Müller et al. 2014).

Regarding the use of new techniques for modeling the stem profile, the mixed-effect modeling (MEM) is considered promising and usually generates better accurate estimates, as confirmed in the works by Cao \& Wang (2011); Carvalho et al. (2014); MacFarlane \& Weiskittel (2016).

One of the MEM characteristics is the fixed- and random-effect parameter estimation when repeated measurements are taken from the same specimens or grouped data. According to Schabenberger \& Pierce (2002), this adjustment procedure must be used when a data array is grouped or requires random effects.

Despite the proven MEM efficiency, its use at tree taper is relatively recent in Brazil; due to this, few works have been developed, among which we can mention those by Horle et al. (2010); Carvalho et al. (2014); Môra et al. (2014), and Nicoletti (2017).

Once the superiority of mixed models has been confirmed and the scarcity of studies associated with that class of models, this work was intended to assess the estimates gathered by mixed-effect taper functions and the plantation arrangement and spacing effect to the Eucalyptusstem form in an iCLF system.

\section{MATERIAL AND METHODS}

\section{Study area characterization}

Data for conducting this study was gathered from two experimental Crop-LivestockForest integration (iCLF) areas, called dairy iCLF and beef iCLF, implemented by the Brazilian Agricultural Research Company (Embrapa Agrossilvipastoril) in the municipality of Sinop, in northern Mato Grosso State.

According to Köppen's classification, the region's climate is considered as monsoon tropical, with three-month drought, and yearly accumulated rainfall between 2,500 and 2,800 $\mathrm{mm}$, yearly approximate average temperature ranging from 24 to $26{ }^{\circ} \mathrm{C}$, maximum temperatures of $40^{\circ} \mathrm{C}$ and minimum ones of $20^{\circ} \mathrm{C}$, with $380 \mathrm{~m}$ altitude, in addition to a flat landscape and predominance of Red-Yellow Clay Latosol (Alvares et al., 2013). 
Experiments were implemented in February (dairy iCLF) and December (beef iCLF) 2011, under a randomized block design (RBD) with four treatments: Crop-Livestock-Forest (T1), Crop-LivestockForest (T2); Livestock-Forest (T3), and homogeneous eucalyptus plantation (T4).

ForT1 treatment, the Eucalyptus tree plantation arrangement in double rows was adopted, while for T2, a triple row tree arrangement was used. On both treatments (T1 and T2), trees were mixed with 'piatã' grass (Brachiaria brizantha cv. Piatã) pasture integrated with maize for silage and breeding of 'Girolanda' dairy cattle. For T3 treatment, trees were planted on triple rows mixed with 'piatã' grass (Brachiaria brizantha cv. Piatã) and breeding of Nellore beef oxen. T4 only consisted of a homogeneous eucalyptus plantation (Figure 1).

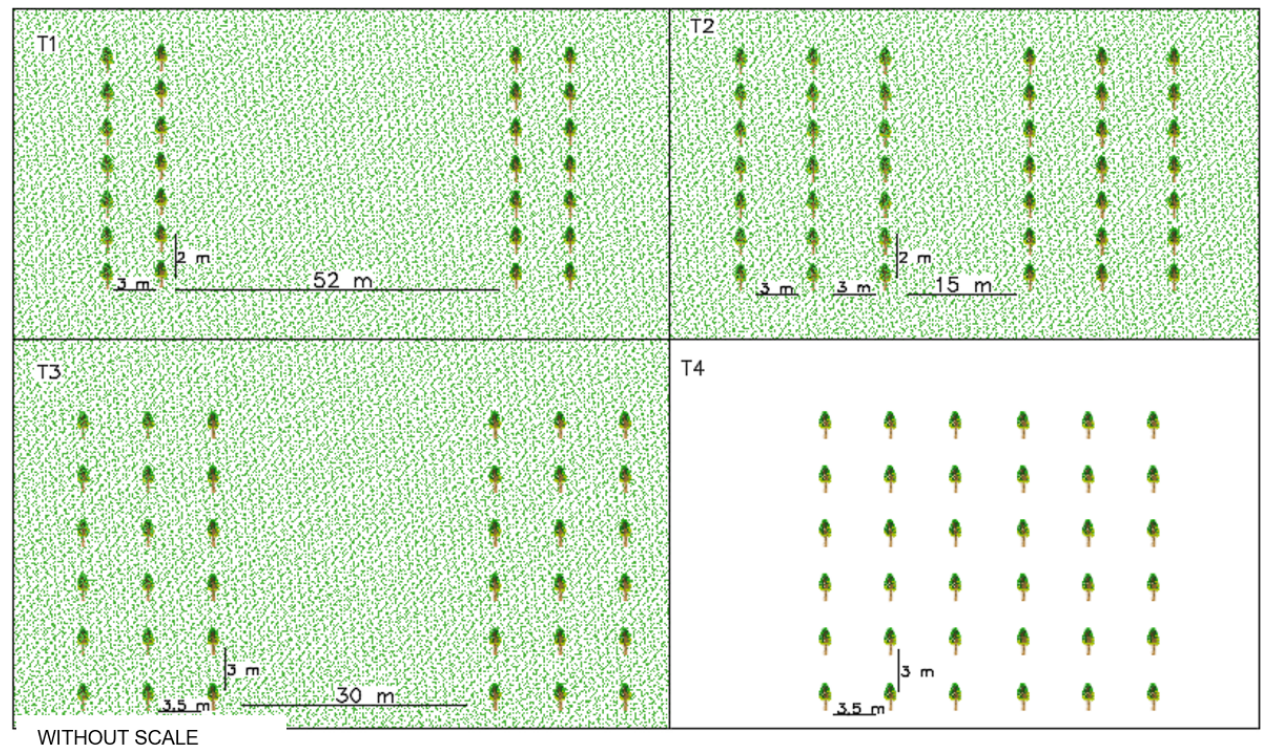

Figure 1. Tree distribution for the different evaluated treatments.

Treatments have been established for different integration arrangements, and the forest component employed was the Eucalyptus grandis $x$ Eucalyptus urophylla hybrid clone. The tree plantation lane orientation was in the East-West direction.

\section{Database}

To gather data, a forest inventory was done establishing permanent patches comprising an $882 \mathrm{~m}^{2}$ area at each treatment center line (T1, $\mathrm{T} 2$, and $\left.\mathrm{T} 3\right)$ and the center of the monoculture (T4) area, comprising 81 trees measured on each patch.

Data was gathered through the destructive cubing of 186 51-month-old trees (Table 1).

Table 1. Treatment description and sampled tree frequency distribution.

\begin{tabular}{ccccccc}
\hline Treatment & Spatial arrangement $(\mathbf{m})$ & árv.ha $^{-1}$ & $\mathbf{N}$ & $\mathbf{L}$ & IMA & Vt $\left.\mathbf{( m}^{\mathbf{3}}\right)$ \\
\hline T1 & $3 \times 2 \times 52$ & 189 & 21 & 2 & 9.13 & 40.61 \\
T2 & $3 \times 2 \times 15$ & 714 & 56 & 3 & 28.1 & 124.1 \\
T3 & $3.5 \times 3 \times 30$ & 270 & 54 & 3 & 7.9 & 36.9 \\
T4 & $3.5 \times 3$ & 952 & 55 & $x$ & 31.2 & 145.7 \\
Total & & 1967 & 186 & & & \\
\hline
\end{tabular}

árv.ha-1: number of trees per hectare; árv: trees; N: number of cubed trees; and L: number of planting lines with trees for treatments (T1, T2, and T3); IMA= yearly average increase per treatment; $\mathrm{Vt}=$ total volume per treatment.

The selection of trees for cubing was done considering the diametric distribution of trees for each treatment (Figure 2), gathered from forest inventory data, establishing ten diametric classes and five cubed trees per class for T2, T3, and T4 treatments. For the T1 treatment, since 
trees from the two smaller classes were not so representative, suppressed, and mostly dead, eight classes have been established, and three specimens were sampled per diametric class.

$\mathrm{T} 1$

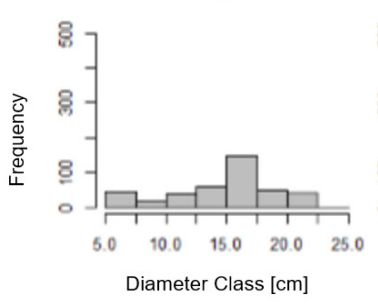

T2

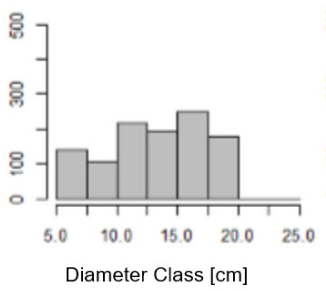

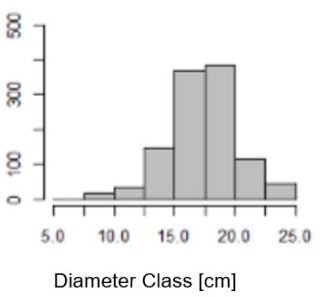

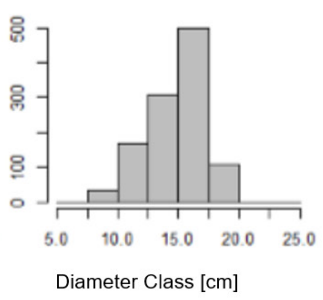

Figure 2. Tree diametrical distribution for each treatment.

Selected specimens were felled, sawed, and their diameters measured with bark at the following heights: $0.10 \mathrm{~m} ; 0.70 \mathrm{~m} ; 1.30 \mathrm{~m}$, and then at $1.0 \mathrm{~m}$-long intervals, up to a minimum diameter of approximately $1.0 \mathrm{cmat}$ the thinner tip. For every tree, besides diameters (di) measured at different heights (hi), the diameter was also measured at $1.30 \mathrm{~m}$-high from the ground (d) and at the total height (h). The individual tree volume finding, regarded as real, was established by the rigorous cubing method with absolute Smalian sections.

\section{Stem taper}

For the tree taper study, two modeling techniques have been used: traditional regression (nonlinear regression) (TR) with all fixed parameters (common to all trees) and the mixedeffect modeling (MEM) with specific parameters per tree, when the tree itself was considered as a random effect for modeling.

\section{Traditional regression (TR)}

For studying the eucalyptus tree stem form in the different treatments using TR, nonsegmented (NS), segmented (S), and variable form (VF) taper models were adjusted and assessed (Table 2).

Table 2. Eucalyptus-adjusted taper functions in an iCLF system.

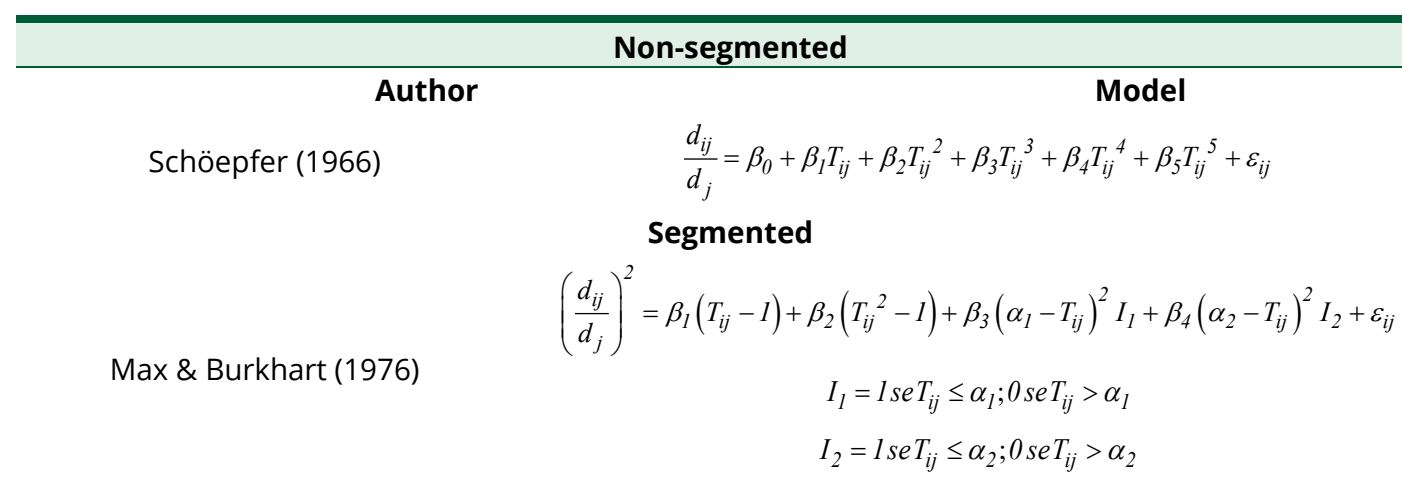

Variable form

Perez et al. (1990)

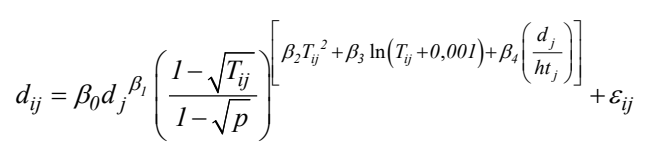

Where: $d_{j}=$ chest height diameter with bark $(\mathrm{cm}) ; h t_{j}=$ total height $(\mathrm{m})$; $d i=$ diameter with bark $(\mathrm{cm})$ at $h_{i j}$ height $(\mathrm{m})$; $h_{i j}=$ height (m) where the $d_{i j}$ diameter is found; $T_{i j}=h_{i j} / h t_{j} ; \beta_{i}=$ coefficients; $\alpha_{i}=$ inflection points; $\varepsilon_{i j}=$ random error; $p=p$ value used was that of Max and Burkhart's model $\alpha_{1}$ coefficient, which corresponds to the inflection point where steam form changes from neiloid to paraboloid. 


\section{Mixed-effect modeling (MEM)}

The MEM procedure has been used with the fifth-degree polynomial (Equation 1), proposed by Schöepfer (1966), to obtain diameter estimates along tree stems in different treatments.

$$
\frac{d_{i j}}{d_{j}}=\varnothing_{0}+\varnothing_{1} T_{i j}+\varnothing_{2} T_{i j}{ }^{2}+\varnothing_{3} T_{i j}{ }^{3}+\varnothing_{4} T_{i j}{ }^{4}+\varnothing_{5} T_{i j}{ }^{5}+\varepsilon_{i j}
$$

where: $d_{i j}$ : diameter with bark $(\mathrm{cm})$ of thei-th tree at the j-th height $(\mathrm{m})$; $\mathrm{d}_{\mathrm{i}}$ : diameter at $1.3 \mathrm{~m}$ above ground level $(\mathrm{cm})$ of the i-th tree; $\emptyset$ : fixed and random parameters; $T_{i j}$ : relative height $\left(\frac{h i}{h}\right)$ of the $\mathrm{i}$-th tree at the j-th stem position; and $\varepsilon_{\mathrm{ij}}$ : random error.

The fifth-degree polynomial has been adopted because it is a widely used non-segmented model when the purposes are to quantify multi-products and assess the stem form at different ages and spacing.It is due to the ease of adjustment and accuracy, which is usually provided by this model (Figueiredo Filho et al., 2015). The general MEM structure applied to the taper function used is represented in Equation 2.

$\varnothing=\left[\begin{array}{l} \\ \varnothing_{0} \\ \varnothing_{1} \\ \varnothing_{2} \\ \varnothing_{3} \\ \varnothing_{4} \\ \varnothing_{5}\end{array}\right]=\left[\begin{array}{c} \\ \beta_{0} \\ \beta_{1} \\ \beta_{2} \\ \beta_{3} \\ \beta_{4} \\ \beta_{5}\end{array}\right]+\left[\begin{array}{c} \\ b_{0} \\ b_{1} \\ b_{2} \\ b_{3} \\ b_{4} \\ b_{5}\end{array}\right]=\beta+b$

where: $\mathrm{b} \sim \mathrm{N}\left(0, \sigma^{2}\right)$; and $\varepsilon \sim \mathrm{N}\left(0, s^{2} \mathrm{I}\right)$. The $\beta$ vector stands for fixed effects, while the $\mathrm{b}$ vector, random effects.

The model adjustment was done in a nonlinear fashion, applying mixed-effect nonlinear modeling of the package $(n / m e)$ implemented at $\mathrm{R}$, adopting trees as a random effect, to increase the diameter prediction accuracy. The technique was also applied to group data gathered from different integration spacing and arrangements, looking for possible diameter estimate improvements along the stem.

\section{Estimate accuracy and model identity test}

Model adjustments and statistical procedures have been conducted using Software R, version 3.3 (R Core Team, 2018). TR adjustments were performed using the $n / s$ function through an iterative method, using the Gauss-Newton algorithm based on minimizing the sum of nonlinear squares. After the adjustment, the adjusted equation coefficient significance has been assessed through a t-Student test at 5\% significance. The TR and MEM precision and accuracy has been assessed based on the following statistical criteria: greater Pearson's squared linear correlation coefficient $\left(r_{y \hat{y}}^{2} \%\right)$ between the diameter variable along the actual and estimated stem, smaller estimate standard error value $\left(\mathrm{S}_{\mathrm{yx}} \%\right)$, and residue graph analysis in percentage scale (E\%).

After adjusting models and assessing estimates, Schöepfer's equations have been compared through the model identity test proposed by Graybill (1976) and proved by Regazzi (1993). According to Regazzi (1996), the test hypothesis has been formulated as follows: Initial hypothesis ( $\mathrm{HO})$ : The complete model does not statistically differ from the reduced model; Alternate hypothesis $(\mathrm{H} 1)$ : at least one of the complete models statistically differs from the reduced model. 


\section{RESULTS AND DISCUSSION}

Diameter variation along the stem due to the tree's relative height (hi) may be seen in Figure 3.

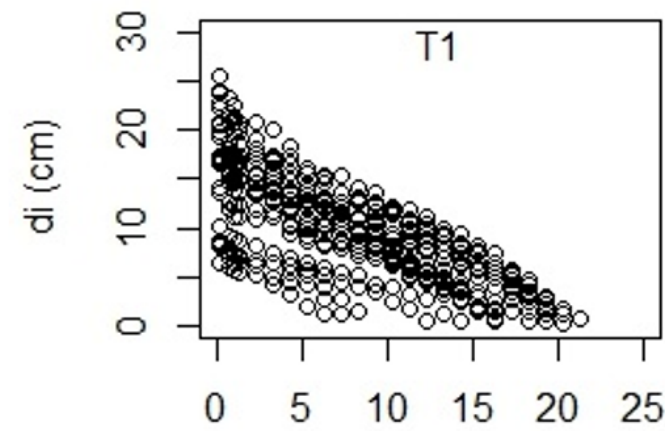

hi $(\mathrm{m})$

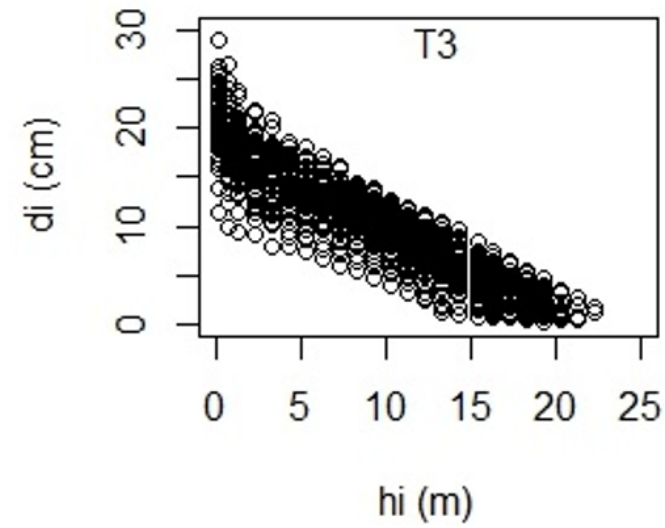

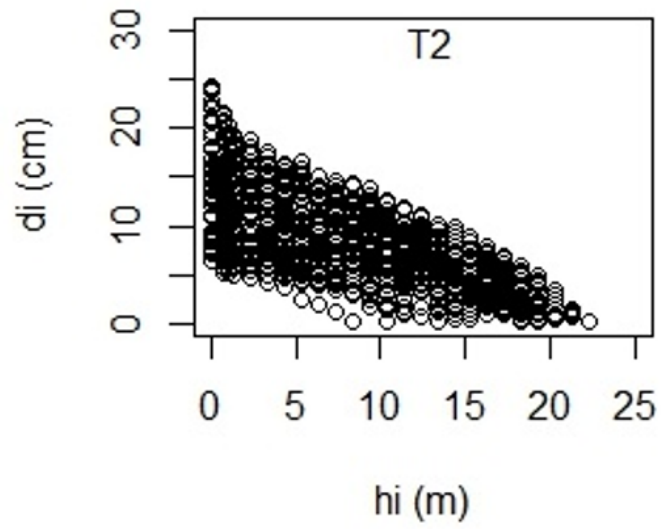

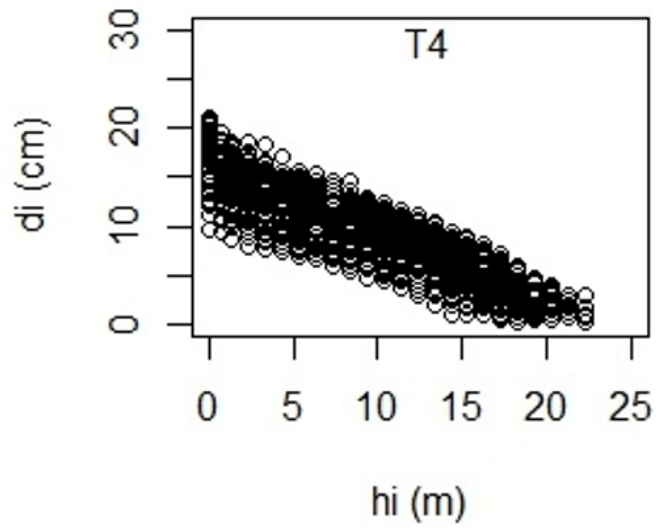

Figure 3. Diameter (di) variation along sampled tree stem for the different treatments.

The biggest diameter variation according to the relative height has been noticed on the T1 treatment. Such a condition may be justified because trees were arranged peripherally in the experiment, subjected to higher wind influence and lesser intraspecific competition, which favors obtaining more irregular stems.

\section{Traditional regression (RT)}

The equation coefficient significance test has featured significant results $(p \leq 0.05)$ in all treatments, indicating that independent variables $(\mathrm{d}, \mathrm{h}, \mathrm{di}, \mathrm{hi})$ explain diameter variability along tree stems (Table 3 ).

Estimates for the different treatments have resulted in a correlation coefficient $\left(r_{y y}^{2}\right.$ )ranging from 96.559to99.042, and the average standard error in percentage $\left(\mathrm{S}_{\mathrm{yx}}\right)$ ranging from 5.19 to $10.53 \%$. The T1 treatment, which has featured the biggest data variation, has resulted in the biggest standard error compared to the others.

Upon analyzing the accuracy among the three models, it has been noted that the average standard error variation was smaller than $2 \%$ for all treatments, which shows a little variation of such models for describing tree stem taper.

Residue graphs have allowed us to access how errors have behaved along tree stems; it was noticed that errors had featured a non-constant variance, featuring a trend to increase it as the tree height increases (Figure 4). 
Table 3. Accuracy coefficients and statistics for the different treatments.

\begin{tabular}{|c|c|c|c|c|c|}
\hline \multirow{2}{*}{ Models } & \multirow{2}{*}{ Coeff./Stat. } & \multicolumn{4}{|c|}{ Treatments } \\
\hline & & T1 & T2 & T3 & T4 \\
\hline \multirow{11}{*}{ Schöpfer } & $\hat{\beta}_{0}$ & $1.1879 *$ & $1.2325^{\star}$ & $1.2032 *$ & $1.1529 *$ \\
\hline & $\hat{\beta}_{1}$ & $-2.9261 *$ & $-4.1329 *$ & $-3.6102 *$ & $-2.7233^{*}$ \\
\hline & $\hat{\beta}_{2}$ & $9.6294 *$ & $17.4462^{*}$ & $13.0845^{*}$ & $9.6213^{*}$ \\
\hline & $\hat{\beta}_{3}$ & $-19.8872 *$ & $-39.2908^{*}$ & $-27.3043^{*}$ & $20.5732 *$ \\
\hline & $\hat{\beta}_{4}$ & $18.7630^{*}$ & $39.2908^{*}$ & $25.6765^{\star}$ & $19.6912^{*}$ \\
\hline & $\hat{\beta}_{5}$ & $-6.7294^{*}$ & $-14.7387^{\star}$ & $-9.0717^{*}$ & $-7.1829 *$ \\
\hline & $r_{y \hat{y}}^{2}(\%)$ & 97.160 & 97.987 & 98.559 & 98.835 \\
\hline & $\mathrm{S}_{\mathrm{yx}}(\%)$ & 9.62 & 7.89 & 6.63 & 5.37 \\
\hline & $\hat{\beta}_{1}$ & $-2.7357^{\star}$ & $-5.8461 *$ & $-3.1554^{*}$ & $-4.4123^{*}$ \\
\hline & $\hat{\beta}_{2}$ & $1.2504^{*}$ & $2.8783^{\star}$ & $1.5723^{*}$ & $2.1758^{*}$ \\
\hline & $\hat{\beta}_{3}$ & $56.7722^{*}$ & $113.5672 *$ & $56.1462^{*}$ & 39.3484 * \\
\hline \multirow{8}{*}{ Max and Burkhart } & $\hat{\beta}_{4}$ & $-0.5116^{*}$ & $-2.4187^{*}$ & $-0.8566^{*}$ & $-1.7423 *$ \\
\hline & $\hat{\alpha}_{1}$ & $0.0838 *$ & 0.0717 & 0.0922 & 0.0912 \\
\hline & $\hat{\alpha}_{2}$ & 0.8601 * & 0.8837 & 0.7959 & 0.8255 \\
\hline & $r_{y \hat{y}}^{2}(\%)$ & 97.271 & 98.225 & 98.654 & 98.879 \\
\hline & $S_{y x}(\%)$ & 9.44 & 7.43 & 6.42 & 5.27 \\
\hline & $\hat{\beta}_{0}$ & $1.0703 *$ & $1.0971 *$ & $1.2536 *$ & $0.9544 *$ \\
\hline & $\hat{\beta}_{1}$ & $0.9647 *$ & $0.9645^{*}$ & $0.9041 *$ & $1.0029 *$ \\
\hline & $\hat{\beta}_{2}$ & $0.4532^{*}$ & $0.4148^{*}$ & $0.4230 *$ & $0.4112^{*}$ \\
\hline \multirow[t]{4}{*}{ Perez } & $\hat{\beta}_{3}$ & $-0.1118^{*}$ & $-0.1269 * *$ & $-0.811 *$ & $-0.0671 *$ \\
\hline & $\hat{\beta}_{4}$ & $0.3386^{*}$ & 0.3671 * & $0.4718^{*}$ & $0.4335^{*}$ \\
\hline & $r_{y \hat{y}}^{2}(\%)$ & 96.559 & 98.466 & 99.042 & 98.908 \\
\hline & $\mathrm{S}_{\mathrm{yx}}(\%)$ & 10.53 & 6.71 & 5.34 & 5.19 \\
\hline
\end{tabular}

Coeff./Stat.=coefficients and statistics; *=significant.

The difficulty in estimating smaller diameters on the stem final portion is common to taper studies (Téo et al., 2013). In other cases, errors can be pronounced at the stem base, as highlighted by Môra et al. (2014).

According to the array of statistics $\left(r_{y y}^{2}, \mathrm{~S}_{\mathrm{yx}} \mathrm{E} \%\right)$, taper equations have featured similar and accurate results for diameter estimation. However, for T1, an accuracy reduction has been noticed, possibly due to the smaller number of sampled trees and more irregular stems. Best adjustments have been noticed on T4; probably, it was a homogeneous and concentrated plantation with more uniform stems.

The fifth-degree polynomial is an easily adjusted non-segmented model both on its linear and nonlinear format and widely used to describe tree stem taper, with accurate results for predicting the eucalyptus stem taper (Souza et al., 2016). The same author has stated that Schöpfer's model is a higher degree polynomial, capable of describing curves with the most varied shapes. According to Figueiredo Filho et al. (2015), the fifth-degree polynomial is the taper function more widely known and used in Southern Brazil. It has been frequently used due to the good quality that the model provides.

Accurate and similar results to those found in this study using Max and Burkhart's segmented model for predicting taper have been noticed by (Müller et al., 2014) . They have 
tested non-segmented and segmented models for eucalyptus taper in a silviculture and a cattle breeding system, recommending Max and Burkhart's model as the most accurate one.

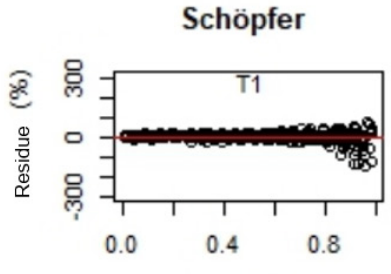

Schöpfer
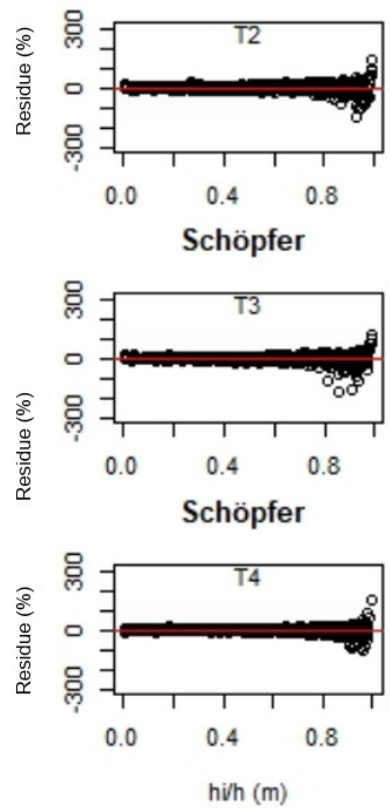

Max e Burkhart

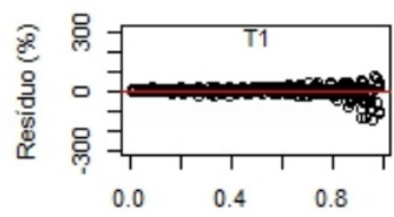

Max and Burkhart
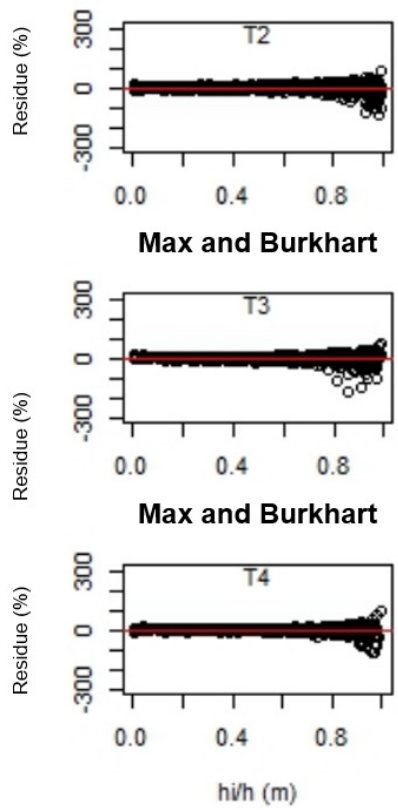

Perez
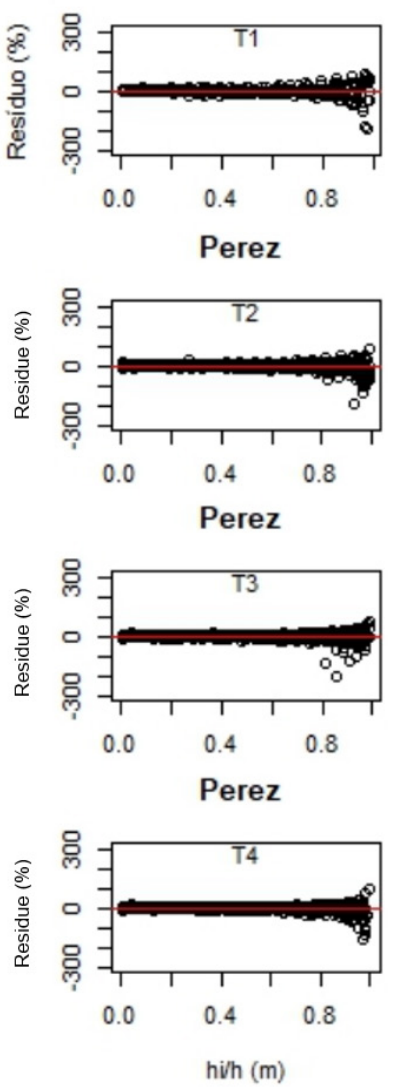

Figure 4. Fixed-effect taper function residues for the different treatments.

Segmented models are quite flexible to model the tree stem form considering the several geometric shapes featured. According to Môra et al. (2014), segmented models divide tree stems into three or more segments, making them more flexible than the non-segmented models. However, they are still little used in Brazil when compared to non-segmented models, and the complexity of making the adjustment partially justifies it.

The variable form model class is still little explored in Brazil. These models are very flexible and easier to adjustthan segmented models and almost always result in accurate estimates. Môra et al. (2014) highlights the importance of this model class and states they are easily adjusted, as well as the non-segmented ones, and take into account the stem form variation, using one or no inflection point. Although few works have been conducted with this model class in Brazil, Môra et al. (2014) has adjusted several variable form models and found accurate results for the eucalyptus diameter estimation with Perez' model, with $\mathrm{S}_{\mathrm{yx}}$ around $5 \%$.

Andrade (2014), when comparing the three model classes used in this study to assess the Eucalyptus grandisx Eucalyptus urophyla hybrid taper, has pointed out that variable form models provide more accurate estimates than non-segmented and segmented models, with considerable potential to be used in Brazil. Môra et al. (2014) has also been one of the pioneers to use variable form functions in Brazil and has added that variable form equations are more accurate than segmented and non-segmented group equations.

\section{Mixed-effect modeling (MEM)}

Since tree taper data feature autocorrelation among observations, several observations are measured within the same specimen, violating the regression analysis assumptions, 
generating problems to coefficient significance tests and inconsistent estimates (Garber \& Maguire, 2003; Yang et al., 2009). Therefore, procedures explaining the correlation among consecutive diameter measurements along the stemby estimating random effects and covariance matrix may result in more accurate estimates, asreported by Garber \& Maguire (2003). (Table 4).

Table 4. Mixed modeling and traditional regression accuracy statistics for diameter estimation along eucalypt tree stem.

\begin{tabular}{cccc}
\hline Model & Adjustment & $\mathbf{r}_{y \hat{y}} \cdot \mathbf{( \% )}$ & $\mathbf{S}_{\mathbf{y x}}(\mathbf{\%})$ \\
\hline \multirow{2}{*}{ Schöpfer } & TR & 97.7982 & 8.1512 \\
& MEM & 98.1235 & 7.5883 \\
\hline
\end{tabular}

The precision statistics indicate that MEM and TR have resulted in accurate estimates; nevertheless, it has been noted that the MEM features a higher correlation among observed and estimated values $\left(r_{y \hat{y}}^{2}\right)$, and a smaller standard error $\left(\mathrm{S}_{\mathrm{yx}}\right)$. In addition to these statistics, residues as percentage dispersion and histograms have been assessed (Figure 5). Again, a higher dispersion was verified, and the di variable overestimates at the tree apical portion. Residue histograms have featured symmetrical distribution and very close to a Normal distribution. However, it shall be noted that the MEM has provided more homogeneous residues at the tree apical portion, which grants a slightly superior estimate regarding the TR.
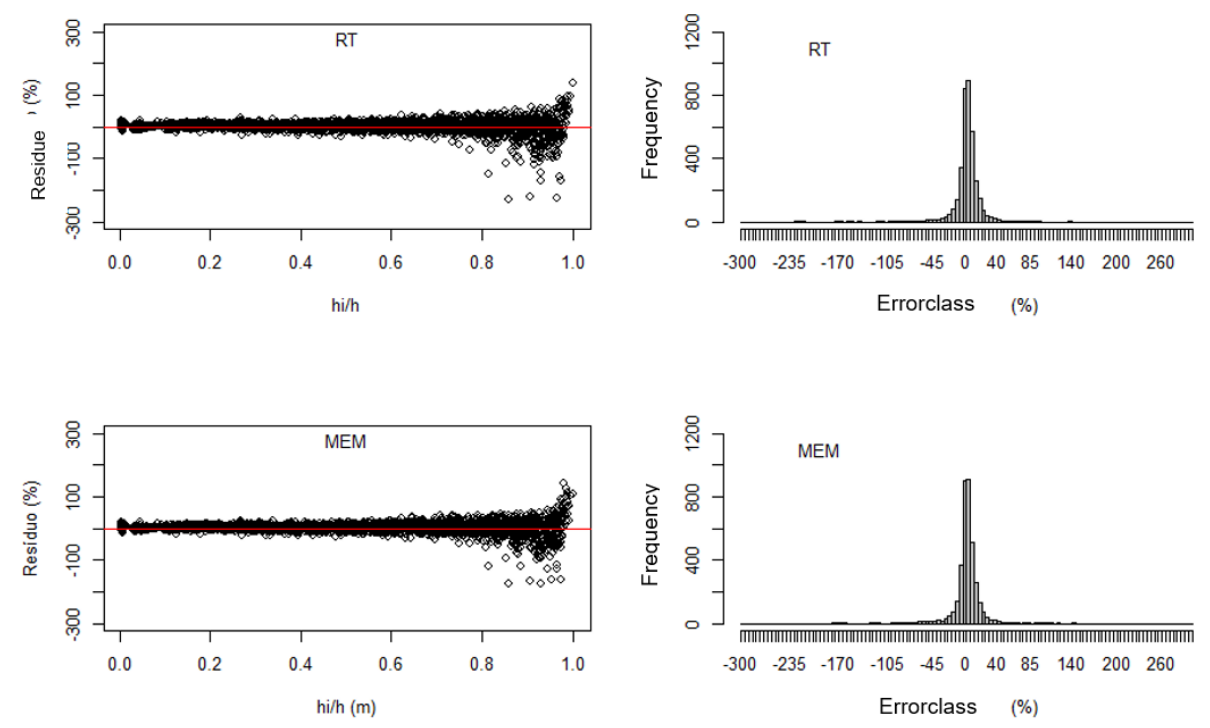

ure 5. Residue distribution and error histogram for traditional regression (TR) and mixed-effect modeling (MEM).

The precision gained by adding the random effect herein noticed for predicting the stem form has also been proven and reported by other authors, such as Cao \& Wang (2011); Carvalho et al. (2014); MacFarlane \& Weiskittel (2016).It is worth mentioning that, in addition to accurate estimates, another MEM important factor is the possibility of grouping different forest conditions (spacing, genetic material, site, diametrical class, and age) and conducting the adjustment procedure with a single database, thus reducing the number of equations and, consequently, databases, which will reflect on the forest inventory costs. Additionally, the MEM allows working with data arrays that do not meet some of the regression assumptions, such 
as independence among observations, random, normal, and identical residue distribution, with zero average and constant variance (Lappi, 1991).

It is important to have studies applying MEM for predicting tree stem form to optimize wood assortments iniCLF. Another major relevant factor is the possibility of reducing the number of sample trees for adjustments. According to Castedo Dorado et al. (2006) and Mendonça et al. (2015), the MEM useallows reducing the sampling intensity required for adjusting models with suitable precision.

The sampling intensity reduction is significant for forest measurement, especially when working with iCLF systems, considering fewer trees in those systems than conventional production systems. Therefore, theMEMis a promising tool for taper estimate and, consequently, for tree wood assortment, which can support eucalyptus forest handling in an iCLF system.

\section{Identity test}

The model identity test has been applied to confirm if the plantation arrangement and spacing influence the tree stem taper. The referred test has been conducted with Schöpfer's model as it is widely used (Figueiredo Filho et al., 2015) and feature accurate adjustments in all treatments, as it can be noticed by the estimated average curve (Figure 6).
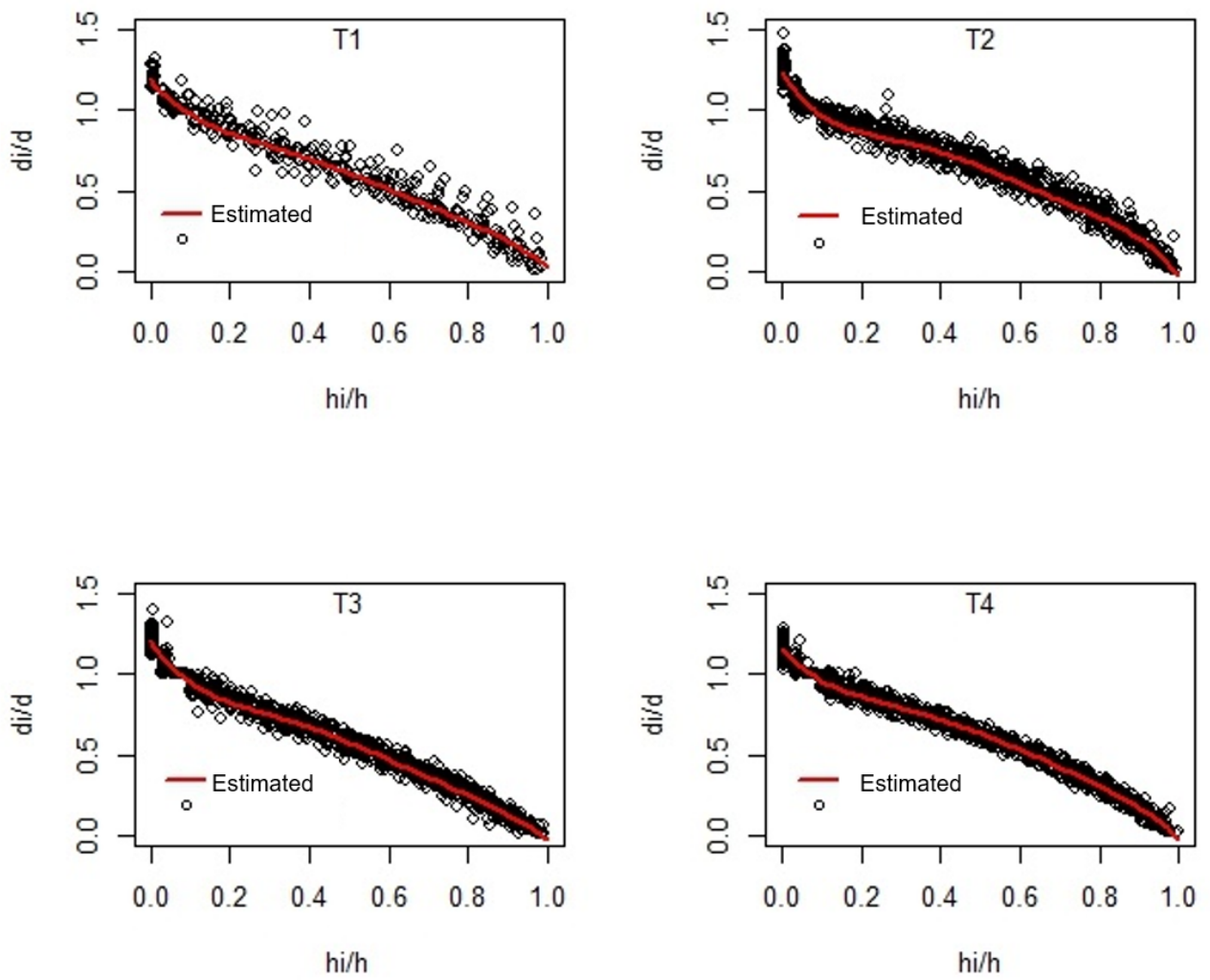

Figure 6. Noticed and estimated stem profile for different treatments.

It has been confirmed through the estimated average curve that, in the $\mathrm{T} 1$ treatment, there were points not shown, and there was a better representation of the average curve in the remaining treatments, which confirms the adjustment superiority on such treatments by statistics and residue graph analysis.

Figure 7 shows the stem taper estimated by Schöpfer's model equationsin different treatments, confirming that the grouped data-adjusted curve features a small difference regarding the curves generated for the other treatments $(\mathrm{T} 2, \mathrm{~T} 3, \mathrm{~T} 4)$. 


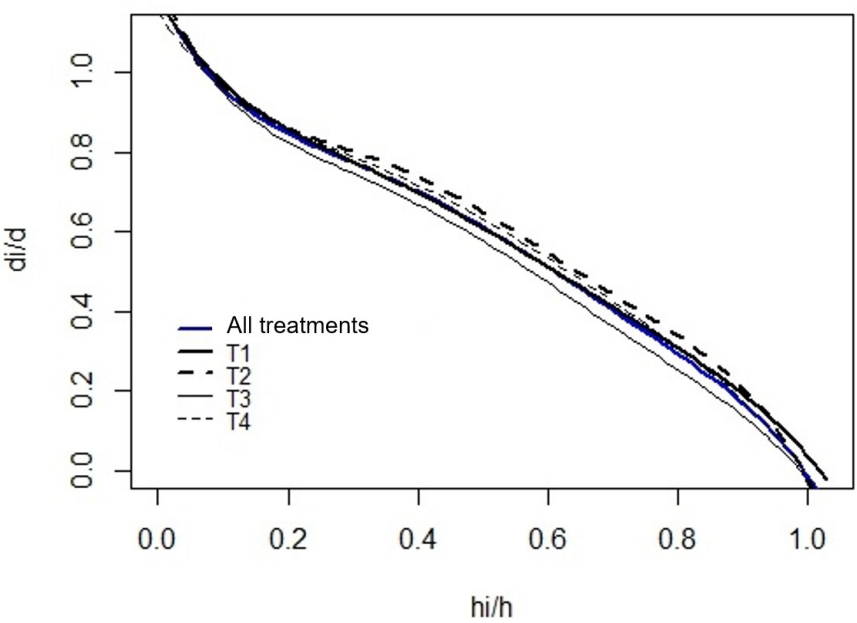

Figure 7. Estimated stem profile for the different grouped treatments.

Despite the subjective analysis of the estimated curves for each treatment (Figure 7), other studies such as those by Larson (1963), Nogueira et al. (2008), and Ferreira et al. (2014) have confirmed that the spacing influences the tree stem form. A higher tree conicity trend has been noted on treatment (T3) based on the aforementioned works. These results follow the general trend noticed on forest stands with different densities. According to Larson (1963), trees growing on lesser dense stands provide more conical stems due to the longer treetop length.

Nogueira et al. (2008) add that larger spacing stands feature a trend of providing more conical trees. Ferreira et al. (2014) report that trees conduced on denser conditions have featured a shorter treetop length due to the increased competition and, consequently, feature more cylindrical shapes than trees grown on larger spacing.

T2 and T4 treatments have apparently provided more cylindrical trees. It may be associated with the smaller spacing where trees have grown, resulting in a smaller vital spacing to grow trees, and consequently, shorter treetop size and more cylindrical stems. According to Campos \& Leite (2013), it is expected that trees grown on smaller spacing feature more cylindrical stemswhen compared to trees at larger spacing. Such characteristic has also been noticed by Pinkard \& Neilsen (2003). Ferreira et al. (2014) have stated that trees grown on denser conditions feature a shorter treetop length due to the shadowing caused by the increased competition.

Nogueira et al. (2008) pointed out that the spacing influences the volume because, for trees with the same diameter and total height, smaller spacing provides trees with larger volumes. These trees feature a stem with a less conical shape. Rance et al. (2012) have noticed that trees with juvenile ages feature more cylindrical stems in smaller arrangements than trees in broader arrangements. Souza et al. (2016) have noticed that less branched trees featured more cylindrical stems than those from more branched trees.

The model identity test confirms the spacing influence in the tree stem form. Initially, the referred test has performed for the four grouped treatments and rejected the initial hypothesis that there is no significant difference among the adjusted equations $(p<0.05)$.

This result allows stating that at least one equation differs from the others, allowing us to conclude that the stem form does not follow the same trend among treatments. Consequently, it is not acceptable to use a single equation to describe the tree stem form for the total data array resulting from plantations in different spacing arrangements in aniCLF system.

Similar results have been noticed by Figueiredo Filho et al. (2015) in a study about the age effect to taper and an assortment of Araucaria angustifolia; Vendruscolo et al. (2016), in a study 
about Tectona grandis tree stem form in different spacing, and also by Souza et al. (2016) studying the Eucalyptus stem form in plantations with different initial densities.

Subsequently, tests have been performed on treatment pairs to establish which differed among them (Table 5). On the combinations assessed between treatment pairs, the $\mathrm{H}_{0}(\mathrm{p}<$ 0.05 ) nullity hypothesis has been rejected for all comparisons, indicating that the stem form or taper in the different treatments statistically differ among them.

Table 5. Identity test results for the different treatment combinations.

\begin{tabular}{cccc}
\hline Treatments & T2 & T3 & T4 \\
\hline T1 & $\mathrm{S}$ & $\mathrm{S}$ & $\mathrm{S}$ \\
T2 & - & $\mathrm{S}$ & $\mathrm{S}$ \\
T3 & - & - & $\mathrm{S}$ \\
\hline
\end{tabular}

$\mathrm{S}=$ significant; $\mathrm{F}_{\mathrm{HO}} \geq \mathrm{F} \alpha ; \mathrm{p}$-value $\leq 0.05$

Significant density results regarding the stem form have been noticed by Pinkard \& Neilsen (2003). They have assessed the influence of six spatial arrangements on the $t$ Eucalyptus nitenstreetop and standing characteristics for a pruning application in northern Tasmania, Australia. Nogueira et al. (2008) have assessed the spatial arrangement's influence on thePinus taeda tree stem form on the 'Planalto Serrano' region at Santa Catarina State in Brazil. Rance et al. (2012), assessing plantations of Eucalyptus grandis subjected to different spatial arrangements and conducted on different sites in southwestern Australia, and Souza et al. (2016) have highlighted having a significant influence of different initial densities in the Eucalyptus stem form in Itamarandiba, Minas Gerais, Brazil.

\section{CONCLUSIONS}

Variable form taper equations have featured better performance and more accurate taper estimates than non-segmented and segmented models.

Plantation spacing and arrangement influences the tree stem form implemented in ani CLF system;

The mixed-effect modeling features greater accuracy for estimating eucalyptus taper in a Crop-Livestock-Forest integration system.

\section{BIBLIOGRAPHIC REFERENCES}

Alvares, C. A., Stape, J. L., Sentelhas, P. C., Gonçalves, J. L. M., \& Sparovek, G. (2013). Köppen's climate classification map for Brazil. Meteorologische Zeitschrift, 22(6), 711-728. http://dx.doi.org/10.1127/0941-2948/2013/0507.

Andrade, V. C. L. (2014). Novos modelos de taper dotipoexpoente-forma para descrever o perfil do fuste de árvores. Pesquisa Florestal Brasileira, 34(80), 1-13. http://dx.doi.org/10.4336/2014.pfb.34.80.614.

Campos, J. C. C., \& Leite, H. G. (2013). Mensuração florestal: perguntas e respostas (4. ed., 605 p.). Viçosa: UFV.

Cao, Q. V., \& Wang, J. (2011). Calibrating fixed- and mixed-effects taper equations. Forest Ecology and Management, 262(4), 671-673. http://dx.doi.org/10.1016/j.foreco.2011.04.039.

Carvalho, S. P. C., Rodrigues, L. C. E., Calegario, N., Savian, T. V., Lima, M. P., Silva, C. A., Mendonça, A. R., \& Nicoletti, M. F. (2014). Modelagemnão linear mista para descrever o afilamento de árvoresclonais de Eucalyptus sp. Scientia Forestalis, 42(104), 605-614.

Castedo Dorado, F., Diéguez-Aranda, U., Barrio Anta, M., Sánchez Rodríguez, M., \& von Gadow, K. (2006). A generalized height-diameter model including random components for radiata pine plantations in northwestern Spain. Forest Ecology and Management, 229(1-3), 202-213.

http://dx.doi.org/10.1016/j.foreco.2006.04.028. 
Ferreira, G. W. D., Ferraz Filho, A. C. F., Pinto, A. L. R., \& Scolforo, J. R. S. (2014). Influência do desbastena forma do fuste de povoamentosnaturais de Eremanthusincanus (Less.) Less. Ciências Agrárias, 35(4), 1707-1720.

Figueiredo Filho, A., Retslaff, F. A. S., Kohler, S. V., Becker, M., \& Brandes, D. (2015). Efeito da idade no afilamento e sortimentoempovoamentos de Araucaria angustifolia. Floresta e Ambiente, 22(1), 50-59. http://dx.doi.org/10.1590/2179-8087.080114.

Garber, S. M., \& Maguire, D. A. (2003). Modeling stem taper of three central Oregon species using nonlinear mixed-effects models and autoregressive error structures. Forest Ecology and Management, 179(1-3), 507-522. http://dx.doi.org/10.1016/S0378-1127(02)00528-5.

Graybill, F. A. (1976). Theory and application of linear model (704 p.). Belmont: Duxbury.

Horle, D. C., Mendonça, A. R., Carvalho, S. P. C., \& Calegario, N. (2010). Modelagem não linear do perfil longitudinal de fustes de Pinus oocarpa. Cerne, 16(2), 177-184. http://dx.doi.org/10.1590/S010477602010000200009.

Lappi, J. (1991). Calibration of height and volume equations with random parameters. Forest Science, 37(3), 781-801.

Larson, P. R. (1963). Stem form development of forest trees. Forest Science, 9(2), 1-41.

MacFarlane, D. W., \& Weiskittel, A. R. (2016). A new method for capturing stem taper variation for trees of diverse morphological types. Canadian Journal Forest., 46(6), 804-815. http://dx.doi.org/10.1139/cjfr-2016-0018.

Max, T. A., \& Burkhart, H. E. (1976). Segmented polynomial regression applied to taper equations. Forest Science, 22(3), 283-289.

Mendonça, A. R., Carvalho, S. P. C., \& Calegario, N. (2015). Modelos hipsométricos generalizados mistos na predição da altura de Eucalyptus sp. Cerne, 21(1), 107-115. http://dx.doi.org/10.1590/01047760201521011191.

Môra, R., Silva, G. F., Gonçalves, F. G., Soares, C. P. B., Chichorro, J. F., \& Curto, R. A. (2014). Análise de diferentesformas de ajuste de funções de afilamento. Scientia Forestalis, 42(102), 237-249.

Müller, M. D., Salles, T. T., Paciullo, D. S. C., Brighenti, A. M., Castro, C. R. T. (2014). Equações de altura, volume e afilamento para eucalipto e acácia estabelecidos em sistema silvipastoril. Floresta, 44(3), 473-484

Nicoletti, M. F. (2017). Modelagem não linear mista e métodobivariado para sortimento da produção de Pinus taeda L. (Tese de doutorado). Universidade Federal do Paraná, Curitiba.

Nogueira, G. S., Leite, H. G., Reis, G. G., \& Moreira, A. M. (2008). Influência do espaçamento inicial sobre a forma do fuste de árvores de Pinus taeda L. Revista Árvore, 32(5), 855-860. http://dx.doi.org/10.1590/S0100-67622008000500010.

Perez, D. N., Burkhart, H. E., \& Stiff, C. T. (1990). A variable-form taper function for Pinus oocarpaSchiede in Central Honduras. Forest Science, 36(1), 186-191.

Pinkard, E. A., \& Neilsen, W. A. (2003). Crown and stand characteristics of Eucalyptus nitens in response to initial spacing: implications for thinning. Forest Ecology and Management, 172(2-3), 215-227. http://dx.doi.org/10.1016/S0378-1127(01)00803-9.

Rance, S. J., Mendham, D. S., Cameron, D. M., \& Grove, T. S. (2012). An evaluation of the conical approximation as a generic model for estimating stem volume, biomass and nutrient content in young Eucalyptus plantations. New Forests, 43(1), 109-128. http://dx.doi.org/10.1007/s11056-0119269-5.

Regazzi, A. J. (1993). Teste para verificaraidentidade de modelos de regressão e a igualdade de alguns parâmetros num modelo polinomialortogonal. Revista Ceres, 40, 176-195.

Regazzi, A. J. (1996). Teste para verificar a identidade de modelos de regressão. Pesquisa Agropecuária Brasileira, 31(1), 1-17.

R Core Team. (2018). R: A language and environment for statistical computing. Vienna, Austria: $\mathrm{R}$ Foundation for Statistical Computing. Retrieved in 2018, March 28, from https://www.R-project.org.

Schabenberger, O., \& Pierce, F. J. (2002). Contemporary statistical models: for the plant and soil sciences (730 p.). Boca Raton: CRC Press.

Schöepfer, W. (1966). Automatisierung des massen, sorten und wertberechnung stenender waldbestande schriftenreihe. Berlin: Wurtt-Forstl. 
Souza, R. R., Nogueira, G. S., Murta Júnior, L. S., Pelli, E., Oliveira, M. L. R., Abrahão, C. P., \& Leite, H. G. (2016). Forma de fuste de árvores de eucalipto em plantios adensados. Scientia Forestalis, 44(109), 33-40. http://dx.doi.org/10.18671/scifor.v44n109.03.

Téo, S. J., Marcon, A., Ehlers, T., Bianchi, J. C., Peloso, A., Nava, P. R., \& Costa, R. H. (2013). Modelos de afilamento para Pinus elliottii em diferentes cidades, na região de Caçador, SC. Floresta, 43(3), 439452. http://dx.doi.org/10.5380/rf.v43i3.30320.

Torres, C. M. M. E., Oliveira, A. C., Pereira, B. L. C., Jacovine, L. A. G., Oliveira Neto, S. N., Carneiro, A. C. O., \& Torres, C. M. M. E. (2016). stimativas da produção e propriedades da madeira de eucalipto em Sistemas Agroflorestais. Scientia Forestalis, 44(109), 137-148. http://dx.doi.org/10.18671/scifor.v44n109.13.

Vendruscolo, D. G. S., Drescher, R., Carvalho, S. P. C., Souza, H. S., Silva, R. S., \& Chaves, A. G. S. (2016). Forma do fuste de árvores de Tectona grandis em diferentes espaçamentos. Advances in Forestry Science, 3(3), 51-54.

Yang, Y., Huang, S., Trincado, G., \& Meng, S. X. (2009). Nonlinear mixed-effects modeling of variableexponent taper equations for lodgepole pine in Alberta, Canada. European Journal of Forest Research, 128(4), 415-429. http://dx.doi.org/10.1007/s10342-009-0286-2.

Authors'Contribution: CLC: Conceptualization, Investigation, methodology, software, Writing - Original Draft, Writing - Review and Editing; RM: Investigation, methodology, software, Writing - Original Draft, Writing - Review and Editing,visualization, validation, supervision; HT: Funding acquisition, Resources, Supervision; JEA: visualization, validation, Writing - Original Draft; SPCC: Methodology, Writing - Original Draft, Validation; DGSV: Methodology, visualization, validation, Writing - Original Draft. 